\title{
Fundamental Sociological Symptoms as a Source of Occurrence of Turbulence in Indonesian Society During The Post-Reform
}

\author{
D. Budimansyah \\ Faculty of Social Science Education, Universitas Pendidikan Indonesia \\ Bandung, INDONESIA \\ budimansyah@upi.edu
}

\begin{abstract}
This paper discusses the extent to which the fundamental sociological phenomenon is the emergence of power centered on an elite group (oligarchy) and the appearance of veiled hatred that became the source of the turmoil of post-reform Indonesian society. The paper argues that the problem lies in the lack of an agreement to develop naturally, and participatory values (normative integration) and rely more on power approach (integration coercive). Indonesia needs to create a civic culture as a cultural agreement to establish harmony among groups in society and one of them through the learning of Sociology.
\end{abstract}

Keywords: oligarchy, socio-cultural animosity, civic culture

\section{INTRODUCTION}

Indonesian political and social life conditions of the New Order (1966-1998) were criticized for lacking reflect the ideals of a democratic society. The presumption for this is that the mistake was rooted in the authority of the state (state agents) through excess of an indoctrination of politics. After the fall of the authoritarian regime, i.e. after indoctrination was over, great hopes arise that the life of the nation will be more democratic. In the era of 'reform', the discourse of citizenship recognizes the rights of citizens as a central issue in a pluralist democratic society. In other words, the struggle and the acquisition of civil rights, human rights and social and political justice are believed to be more easily achieved. However, after almost two decades, it seems that this expectation is not so visible, with the exception of the aspects of freedom of expression where there have been bigger opportunities available than those during the authoritarian regime [1].

On the other hand, in the era of 'democratic transition' Indonesian people are confronted with the various phenomena that really concern people's lives. In the society bad characters emerge as typified by the drastic and fantastic change in social and cultural life. The people who were formerly known as patient, friendly, courteous and good at small talks are now becoming grumpy, abusive, and vindictive. They mistreat fellow human beings in the hustle of the city. People of different villages/tribes savagely fight with each other. Even more tragic, our students are hurting each other in the streets. Level of discipline in our society in various fields of life also does not seem encouraging, even obeying a simple rule such as riding/driving on a street is still very poor [2]. On the basis of this reality it is imperative that we investigate seriously what exactly the source of the aforementioned phenomena is.

\section{FUNDAMENTAL SOCIOLOGICAL SYMPTOM}

Turbulent situations as we feel today after the reform can be explained sociologically because they have something to do with social structures and cultural systems that were built in the past. Analysis of the situations after the 1998 reform reveals there are some fundamental sociological phenomena, which may motivate the upheavals in our society today ${ }^{3}$.

First is a concerning fact. After the collapse of the "autocracy" power structures of the New Order regime, what we get is oligarchy (not democracy) where power is concentrated in a small group of elites, while the majority of the people (demos) remain distant from the sources of power (authority, money, law, information, education, and so on). Although the oligarchy was actually hatched and raised by Suharto's New Order, but later changed dramatically over the fall of the Soeharto regime [3] and they are growing stronger controls [4]. This observation is confirmed by the following facts5: (a) the formal political power is controlled by a small group of political party people through election by which they exploit people's vote only to gain seats in the Parliament. Through the Parliament this group has the right on behalf of the people to carry out their own political agendas, which are at times at odds with the real interests of the people; (b) the charismatic power rooted in traditions and religions is held by a few people who are able to drive people's loyalty and emotions to attain obscured goals for themselves is not clear; (c) formal legal power controlled by law practitioners and enforcers with their expertise and/or authority can regulate who is right and who is wrong; (d) most of the money in this country is in the hands of a small group of people who are actually being cornered politically. This group can buy the "truth" through legal institutions, demonstrations, formation of public opinion through mass media, even the seats in the parliament. Take for example the cases of bribery in the House that involved a number of its members, largely because they were bound by the game of the "buyers of truth" through engineering efforts and policies of certain regulations to fulfil their desires; (e) a small group of local elites have a formal or informal authority on behalf of people's aspirations for their own benefit. This group often voiced separatism, federalism, broad autonomy, even the issue of natives; (f) vocal minority groups who 
frequently commit acts of demonstration on behalf of the ordinary people in ways that often even intrude the general public (vigilantism, violence, sweeping, conflict between mass with security forces and etc.).

It seems all the symbols considered effective for mobilizing the masses have been used by the abovementioned small groups in order to impose their will during the post-reform era. Consciously or not, the elites are now suffering from "political myopia" that is, they utilize elections only for short-term goals. Thus, practically all the nation's moral directions are controlled by a partisan and primordial small group. Politics operates within the meaning of Machiavellian, so the accumulation of resources individual power, such as wealth, position and status, achieved through strategic decisions cleverly, including decisions made while building political alliances and economic or embrace and seize voters in the election [6]. Decentralization results in a number of areas of disappointment to many parties: corruption and money politics is rampant, the reforms in the area walking in place, the district remains barren, and plentiful other diseases. All pathology was born as a result of the basic interests of the "predator" at the local level is not paralyzed as the collapse of the New Order [7]. Quite the opposite change of regime in Jakarta generate new pressures for local elites to utilize as much power delegated to them to protect the economic and political interests of their own [8]. As a result, decentralization does not work as promised by most supporters, some of which even revealed a number of empirical case can be explained by a theoretical analysis based oligarchy [9].

Second, the source of the upheavals in our society today is socio-cultural animosity. These symptoms appeared and even worsened after the collapse of the New Order regime. After the New Order regime was successfully deposed, conflicts in Indonesia occurred not only between supporters of the New Order with the fanatical supporters of the Reform, but it extended into tribal, inter-religious, inter-social between social classes, and between village conflicts. Not only are the conflicts vertical between the upper class and the lower class but they are also often horizontal, among small people. Such are not corrective but destructive conflicts (dysfunctional) leading to a self-destroying nation.

Another feature of the conflicts in Indonesia is they are not only manifest conflicts but even more dangerously are latent conflicts between various groups. Socio-cultural animosity is a socio-cultural hatred that stems from differences in cultural traits and fate differences of past history, so the element of desire for revenge prevails. This covert conflict is latent because a variety of mechanisms of dissemination of hatred take place in almost all institutions of socialization in the community (ranging from families, schools, villages, places of worship, mass media, mass organizations, political organizations, and so on).

It is inevitable this covert socio-cultural animosity is strongly associated with the plurality of the Indonesian society. A real example is destruction of Yugoslavia resulted from the depletion of in-group feeling among ethnic groups, while safety valve institutions to sort out the covert sociocultural animosity did not work effectively. Such is not the determining factor; however, because many other plural societies can build a platform with which a culture of inter-ethnic harmony at a fairly steady level can materialize. As an example, the Malaysian society with the concept of sociocultural development has successfully constructed a civic culture as a cultural agreement to establish interracial and religious harmony. No matter how hard the political conflicts that occurred in Malaysia, this agreement stands strong. Indonesia is a different story. Any political differences have always been linked to the most fundamental cultural differences (especially religion). This is what makes political issues difficult to be resolved. The question is why such things happen? If you look at the integration process of the Indonesian nation, the problem lies in the lack of natural and participatory agreed values (normative integration) and the integration relied more on the power approach (coercive integration). On the basis of this reality, the ideals of the reform to build a new Indonesian society should be realized by building on the results of an overhaul of the whole order of life of the past. The core of these ideals is a democratic civil society, which has an adaptive Indonesian character in the global era.

The era of globalization characterized by the rapid development of science and technology, especially information and communication technology, has turned the world into what seems to be a global village. The world becomes transparent without national boundaries. Such conditions have an impact on all aspects of the society and the nation. In addition, globalization can also affect the mindset, attitudes, and behaviors of the entire people of Indonesia. It has challenged the power of applying the elements of national characters, as affirmed Kenichi Ohmae [10] [11] that in the development of a global society, the geographic and political boundaries of countries are relatively intact. However, the life in a country may not be able to limit the global power of information, innovation, and industries that make up the modern civilization.

\section{BUILDING INDONESIAN CHARACTER}

Modern civilization born from globalization has caused a number of problems and disappointments. Eric Fromm [12] describes the development of Europe as the development of modern civilization. The central theme of the development of this modern civilization, in his view, is the emergence of freedom, which occurs at the level of individuals and the society. At the individual level, the freedom starts from the emergence of self in the process of individuation, is the release of the individual ropes since the dissolution of "umbilical cord" until the first occurrence of a sense of separation between the baby and the mother, and in general the separation of 'I' and 'you' .Inseparability between individuals and their environment provides individuals with the feeling of security, a feeling of oneness (belongingness) and the feeling that s/he is rooted on something. The attainment of individual freedom indicates the loss of three ropes replaced by anxiety, powerlessness, alone less, up rootedness, and doubt; all of which leads to hostility. This individuation cycle occurs in each individual, at any time and at any place.

Personality development at the community level also determines the process of individuation throughout history, which in Western society is the result of the 
struggle, more specifically the result of the struggle for freedom. As in the individual level, this freedom can also be illustrated as clamping the ropes of all kinds of power: church, state, and economic exploitation. As in the level of the individual, this freedom is accompanied by anxiety, powerlessness, alone less, up rootedness, doubt, and hostility.

Through this process of freedom, Fromm describes the emergence of the capitalist system, which occurred in the $15^{\text {th }}$ century (the Medieval Times or the Dark Ages) and the $16^{\text {th }}$ century (the Church Reformation era or the emergence of Protestantism). Capitalism in the $15^{\text {th }}$ century first developed in Italy, which was partly due to the Red Sea becoming the path of European trading activities, and close to the East (including the Arab/Islam), so that Eastern culture could be brought to Europe. The emerging capitalism was noble capitalism. The economy stood on a strong ethical foundation (brotherhood) and very little competition. As a result, capital accumulation was running very slow. Nevertheless, in such a trading system capital had been pivotal.

Since the $16^{\text {th }}$ century, during the Church Reformation, the middle class emerged to the top owing to Luther and Calvin, who craved wealth (as a symbol of success). Their primary teachings are independence and reliance on their own efforts. This is the positive aspect of capitalism as propounded by Protestantism, whose central theme is freedom. The negative side, as stated earlier, is the feeling of insecurity, anxiety, powerlessness, and so on.

Fromm concludes from this analysis that in addition to the need of freedom, people also need dependency or submissiveness. When submissiveness needs are not met, freedom becomes meaningless. The mechanism to escape from freedom then surfaces in the form of masochism, sadism, destructiveness, and automaton [13]. That is how Fromm describes Western capitalism and modern society. The modern society has a strong will strong (such as selfreliance, confidence, hard work), but the society is also faltering. The failure is attributed to the absence of inner peace due to dismissals of religious values.

Disappointment to the modern civilization gives rise to a dream to establish a new society with a new morality (see for example Giddens [14] in "The Third Way" 1998). However, until the end of the $20^{\text {th }}$ century, albeit the emerging independent and voluntary public organizations (such as NGOs, mass organizations and political organizations), our civilization is still faced with various cruelty cases to humans and the environment. It turns out the key to human welfare does not solely lie in the creation of a balanced relationship between state and society, but more fundamentally is the new morality (read: new characters) needs to be instilled into the modern system.

Demands for a new morality, for example, were voiced by the French Revolution: "Liberté, égalité, fraternité" (liberty, equality, and fraternity), but until now it seems only "freedom" is obtained, while "equality" is still far behind. The moral "brotherhood" has almost seen no progress in this modern civilization. Apparently, the same happens in our reform. All groups of the society are ecstatic with freedom, while the spirit of brotherhood as a nation is fading, and consequently equality and justice are difficult to be realized. In view of this, the author argues that the essence of the Indonesian character we need to build in our society is "brotherhood" as a new moral attitude.

Bellah [15], a United States sociologist also stresses the importance of a new moral revival that is able to produce more functional underlying social institutions and social relations between the community and the state as well as among citizens. He remarks that all that has degraded human dignity is the result of our social choices, which we standardize into social institutions. New choices need to be made to amend this, which requires a system of values, for all options have a moral and ethical foundation.

Analysis of social institutions connotes questioning: "how are we supposed to live?" and "how do we think about how we live?" Social institutions that regulate how we live our life have been rather dysfunctional or are not in accordance with the ideal values. The ideal values are merely stored in the repertoire of our culture, not effectively regulating our behavior in the existing social order.

Another US sociologist Etzioni [16] also echoes a similar disappointment against modern civilization by taking the United States as example. The American society, according to Etzioni, needs to develop individualism, which has been rooted in their culture along with the communitarian values . In other words, a balance between the rights (ego oriented) and responsibilities (majority oriented) is called for. This line of thought is highly relevant in rectifying the phenomena that have occurred in our society since the colonial period until the New Order in which the people's rights were always abused by the government and the state. During the reform era, the people are suddenly suffering from the symptoms of "a strong sense of entitlement" that is, tendency to demand the rights (by force and violence if necessary) and reluctance to accept responsibilities for the public interest.

Etzioni [16] realizes the formation of a communitarian society can only be realized through a systematic social movement. That is why his group and he declared commitments as part a "communitarian" movement as follows: (1) we must be able to create a new morality that does not interfere with people's private lives (anti Puritanism); (2) we must maintain a "law and order" without leading to a "police state" by carefully designing the authority and power of government; (3) we have to save the lives of families without limiting the rights of their members in a discriminatory manner (e.g. imposing a domestic role to women); (4) schools should be able to provide moral education, without indoctrinating young children; (5) we must strengthen community life without becoming fanatics and hostile to other communities; (6) we must increase the social responsibility not as a limitation of our rights, but rather as balancing of rights that we have acquired. The bigger the rights, the greater the responsibilities; (7) the struggle of personal interests must be balanced with a commitment to the community, without having to be victim for the group. Therefore, infinite personal greed should be replaced by socially beneficial "vested interests" and the opportunity passed by the community; (8) the authority of the government must be maintained without eliminating the opportunity for all citizens to convey their opinions and interests. 


\section{REPOSITIONING THE ROLE OF SOCIOLOGY LEARNING}

All of that is the core of communitarian moral attitudes offered by Etzioni [16], i.e. agreement of modern humans for the creation of new moral, social, and public order based on the reinforcement of the value of "togetherness", without any Puritanism and repression. The spirit to cultivate new moral for this failing modern civilization is also evident from the ideas of Giddens in "The Third Way" whereby he fights for social democracy whose central themes are solidarity, equality and security as well as the active role of the state.

The concept of the Indonesian character in this paper basically refers to the communitarian moral attitude with the spirit of the personality of Indonesia animated by the values of Pancasila (the five principles) and norms that are based on the Constitution of the Republic of Indonesia Year 1945. Building the Indonesian character, therefore, is a process of providing a more independent position of citizens in relation to the state, fostering a democratic ethos that not only emphasizes individual rights and the rule of law, but also capitalizes on improvement of moral relationship among citizens, instilling the value of harmony that generates concern for all citizens and the fate of an entire nation.

At the end of this paper let us focus our attention on the existence of Sociology teaching in schools in the context of the development of young generation into adult citizens. A child is a hypothetical community member or an "unfinished" member of the society because s/he still needs to be educated to become an adult citizen who is aware of his/her rights and responsibilities as a member of society [16].

The society highly expects the younger generation to be good citizens and to participate in public life. Such an expectation is more accurately described as a growing concern, especially in a democratic society. There is a mounting evidence that indicates that none of the countries, including Indonesia, has reached a level of understanding and acceptance of the rights and responsibilities among the entire people to support the social life of Indonesia based on the Divinity values, compassion for fellow God's creation, and maintaining the integrity of the nation-state, coupled with the spirit of consensus, and justice for all. Sociology learning should be a major concern. No task is more important than the development of the effective, noble, and well-educated citizens. The nation is to be nurtured by people who have the knowledge, skills and character s. Without a true commitment to the fundamental values and principles in the society, a civilized society is impossible to materialize. Therefore, the task for educators, policy makers, and members of a civil society is to campaign the importance of Sociology to the whole society, agencies and levels of the government as a vehicle to educate children to become adult citizens.

\section{CONCLUSIONS}

To be able to nurture children to become good members of society, the following strategic steps are essential. First, Sociology learning needs to be revitalized as a curricular course in formal educational institutions (school/college) and no formal educational institutions, which acts as a vehicle for breeding and empowerment of children and youth in accordance with their potential to become citizens of Indonesian who are fully aware of their rights and responsibilities. The educational process involves psycho-pedagogic aspects. Therefore, the author dubs this approach as a psycho-pedagogical development approach.

\section{REFERENCES}

[1] Kalidjernih, F.K. Cita Sipil Indonesia Pasca-Kolonial: Masalah Lama, Tantangan Baru, Jurnal Acta Civicus, Vol.1 No.2, April 2008. hlm.127-146.

[2] Budimansyah, D., Fitriasari, S., Iswandi, D. Model AIDA Untuk Meningkatkan Kesadaran Siswa Berlalulintas di Jalan Raya, Laporan Penelitian Hibah Kemristekdikti, 2015.

[3] Winters, J.W. Oligarchy and Democracy in Indonesia, in Indonesia Journal, Special Edicion, Wealth, Power, and Contemporary Indonesian Politics, Cornell Southeast Asia program Publications, No.96, October 2013, pp.11-34.

[4] Robinson, R. \& Hadiz, V. R. The Political Economy of Oligarchy and the Reorganizing of Power in Indonesia, in Indonesia Journal, Special Edicion, Wealth, Power, and Contemporary Indonesian Politics, Cornell Southeast Asia program Publications, No.96, October 2013, pp.35-57

[5] Wirutomo, P. Membangun Masyarakat Adab, Naskah Pidato Pengukuhan Jabatan Guru Besar tetap Dalam Bidang Sosiolog Pada Fakultas Ilmu Sosial dan Ilmu Politik Universitas Indonesia, 2001 .

[6] Liddle, R.W. Improving the Quality of Democracy in Indonesia in Indonesia, in Indonesia Journal, Special Edicion, Wealth, Power, and Contemporary Indonesian Politics, Cornell Southeast Asia program Publications, No.96, October 2013, pp.59-80.

[7] Hadiz, V. R. Localising Post-Authoritarian Indonesia: A Southeas Asia Perspective. Standford, CA: Standfoer Univwrsity Press, 2010.

[8] Robinson, R. \& Hadiz, V. R. The Political Economy of Oligarchy and the Reorganizing of Power in Indonesia, in Indonesia Journal, Special Edicion, Wealth, Power, and Contemporary Indonesian Politics, Cornell Southeast Asia program Publications, No.96, October 2013, pp.35-57

[9] Aspinal, Ed. \& Mietzner, M. editor. Problem of Democratisation in Indonesia: Elections, Institutions and Society. Singapore: ISEAS, 2010

[10] Ohmae, K. The End of Nation State: The Rise of Regional Economies, London: Harper Collins, 1996

[11] Ohmae, K. Borderless World: Power and Strategy In The Interlinked Economy, London: Harper Collins, 1999.

[12] Fromm, E. Lari Dari Kebebasan, penerjemah Khamdani, Yogyakarta: Pustaka Pelajar, 1997.

[13] Budimansyah, D. Membangkitkan Karsa Umat, Bandung: Penerbit Genesindo Pustaka Utama, 2004.

[14] Giddens, A. The Third Way: The Renewal of Social Democracy, London: Polity Press, 1998.

[15] Bellah, R. et.al. The Good Society, New York: Vintage Books, 1999.

[16] Etzioni, A. The Spirit of Community: The Reinvention of American Society, New York: Simon and Schuster, 1993. 